\title{
THE EFFICACY OF NEWLY SYNTHESISED AGENT AND NATURAL ANTIOXIDANT TREATMENT IN DIABETIC AND HYPERTENSIVE RATS.
}

\author{
${ }^{1} J a n k y o v a ́$, S. $-{ }^{1}$ Adameová, A. - ${ }^{1}$ Slažneva, J. - ${ }^{2}$ Navarová, J. $-{ }^{3}$ Drobná, V. - \\ ${ }^{4}$ Csollei, J. - ${ }^{1}$ Račanská, E. \\ ${ }^{1}$ Department of Pharmacology and Toxicology Faculty of Pharmacy, \\ Comenius University, Bratislava, Slovak Republic \\ ${ }^{2}$ Institute of Experimental Pharmacology and Toxicology, \\ Slovak Academy of Science, Bratislava, Slovak Republic \\ ${ }^{3}$ Institute of Pharmacology and Clinical Pharmacology, Faculty of Medicine, \\ Comenius University, Bratislava, Slovak Republic \\ ${ }^{4}$ Faculty of Pharmacy, University of Veterinary and Pharmaceutical Sciences, \\ Brno, Czech Republic
}

\begin{abstract}
Hypertension that develops as the result of cardiovascular damage in diabetes is one of the serious complications of diabetes. The aim of this study was to evaluate the changes in levels of oxidative stress and in endothelial NO synthase (eNOS) and heat shock protein 90 (Hsp90) expressions after the treatment of diabetic rats with a newly synthesised heteroarylaminoethanolic derivative 4/1E with potentially beta-adrenergic blockade effects and a strong antioxidant Pycnogenol ${ }^{\circledR}$. The treatment of 6 -weeks duration was indicated in the group of diabetic Wistar rats (DL; streptozotocin (STZ) $3 \times 25 \mathrm{mg} / \mathrm{kg}$ i.p.) and hypertensive rats (HL, STZ) with $4 / 1 \mathrm{E}$ in the dose $10 \mathrm{mg} / \mathrm{kg}$ i.p. or with Pycnogenol ${ }^{\circledR}$ (DP, HP) in the dose $20 \mathrm{mg} / \mathrm{kg}$ p.o. Animals in control groups $(\mathrm{C}, \mathrm{H}, \mathrm{D})$ received vehiculum. The levels of oxidative stress were assessed in kidney and liver as the activity of $\mathrm{N}$-acetyl- $\beta$-D-glucosaminidase (NAGA) and the levels of thiobarbituric acid reactive substances (TBARs). The expression of eNOS and Hsp90 was assessed from the hearts of all animals using SDS-Page and Western blotting.

In our study the effects of newly synthesised drug 4/1E and Pycnogenol ${ }^{\circledR}$ on the levels of oxidative stress were comparable only in diabetic animals. The expression of eNOS was decreased in diabetic, but not hypertensive animals. The treatment with $4 / 1 \mathrm{E}$ did not affect the expression of eNOS unlike the treatment with Pycnogenol ${ }^{\circledR}$ after which the expression was significantly increased. The expression of Hsp90 was increased in both hypertensive and diabetic animals. The treatment with 4/1E was more effective in decreasing Hsp90 expression in both groups of animals than the treatment with Pycnogenol ${ }^{\circledR}$.
\end{abstract}

Keywords: diabetes - hypertension - eNOS - Hsp90 - Pycnogenol - 4/1E

28 


\section{INTRODUCTION}

The incidence of cardiovascular disorders in diabetic subjects is higher and more serious than in those without this comorbidity. Hyperglycaemia together with diabetes represents the major factor in the development of vessel dysfunction. Diabetic patients are known to have increased risk of coronary atherosclerosis development, macroangiopathies, autonomic dysfunction and diabetic cardiomyopathy.

The main factor responsible for the development of diabetic complications is hyperglycaemia that causes the formation of free radicals (oxidative stress) and endothelial damage by various mechanisms. N-acetyl- $\beta$-D-glucosaminidase (NAGA) and the levels of thiobarbituric reactive substances (TBARs) are commonly used to assess oxidative stress levels in tissues. NAGA is an enzyme distributed in the lysosomes of a cell that is released after damage and thus is a good predictive factor of enzymatic disturbances. The levels of oxidative stress can be assessed by the peroxidation of lipids. The lipoperoxidation product - malondialdehyde - can be assessed as the levels of thiobarbituric acid reactive substances, increased concentration of which was found in diabetic untreated animals [1].

The direct toxic effect of hyperglycaemia is most likely mediated by activation of protein kinase $\mathrm{C}(\mathrm{PKC})$, which increases the permeability of the endothelium. The origination of free radicals leads to increased formation of diacylglycerol (DAG) [2] that consequently activates PKC. Pro-oxidants bind to the catalytic domain of PKC, the enzymes cease inhibition and the phosphorylation of transcription factors involved in angiogenesis initiates. The processes following the activation of PKC lead to increase of vascular permeability, NO dysregulation, increase of leucocytic adhesion and vasoconstriction and to the changes in the blood flow [3]. The activation of PKC induced by hyperglycaemia, oxidative stress and triggering of hexosamine pathway are considered to be the key points in endothelial NO-synthase (eNOS) activity decrease.

Another considerable determinant in the development of vessel dysfunction is the reduction in NO bioavailability. The main enzyme involved in the formation of NO is endothelial NO-synthase, whose function is dependent on the disposal of the substrate and cofactors. It is regulated by humoral, mechanical and pharmacological stimuli that involve the phosphorylation of the enzyme by activation of kinases and phosphatases, on one hand, but also the influx of calcium ions and protein-protein interactions, on the other hand. Heat shock protein 90 (Hsp90) is a molecular chaperone participating in the association and stabilisation of several proteins including NO-synthases [4]. The interaction between Hsp90 and eNOS leads to stabilisation of this complex and is necessary for the proper function of eNOS.

The regulation of eNOS is maintained by protein-protein interaction of eNOS with Hsp90 and caveoline-1. The increased production of Hsp90 was observed in the case of hypertension-induced kidney failure [5]. Similarly, in SHR rats the Hsp90 expression was increased in the left ventricle and mesenteric arteries, but not in the aorta, compared to the normotensive animals [6].

Due to the main role of oxidative stress in the pathogenesis of diabetes-induced cardiovascular damage, it is appropriate to use antioxidant treatment in the therapy 
of hypertension and diabetes [7]. According to the primary structure of antioxidant carvedilol used in the treatment of hypertension in diabetic patients, there was designed at the Faculty of Pharmacy, Veterinary University in Brno a new potentially acting betablocking agent - a derivative with heteroarylaminoethanolic structure - the agent 4/1E (unpublished data). Based on its structure similar to carvedilol and on primary screening performed in our lab [8] we focused on its potential to affect the expression of eNOS and Hsp90. The effectiveness of the administration of $4 / 1 \mathrm{E}$ is compared to the effectivity with natural antioxidant - Pycnogenol $^{\circledR}$, whose effects were demonstrated in many studies [9-11].

\section{METHODS}

\section{Animals}

For the experiment, male Wistar rats (150-200 g, Dobra Voda, SR) and male SHR rats (200-250 g, Dobra Voda, SR) were used. They were randomised in eight groups. The animals were housed in a quarantine facility for 7 days before the experiment began. Throughout the experiment, the animals were randomised in groups of four in cages of the type T4 Velaz (Prague, Czech Republic) with the bedding composed of wood shavings (exchanged daily). The animals had free access to a standard commercial diet and water. The animals were kept under a stable regimen of $12 \mathrm{~h}$ light/12 h darkness. All procedures involving the use of experimental animals were approved by the State Veterinary and Food Administration of the Slovak Republic. The investigation conforms to the Guide for the Care and Use of Laboratory Animals published by the US National Institutes of Health (NIH Publication No. 85-23, revised 1985).

\section{Inducing of diabetes and treatment}

After the randomisation of the animals, diabetes was induced by administration of streptozotocin i.p. (STZ, Sigma, St. Louis, MO, USA) three days sequentially. STZ was dissolved in citrate buffer $(0.1 \mathrm{~mol} / \mathrm{l}, \mathrm{pH}=4.5)$. The animals were fasting twelve hours before the administration of STZ. After the inducement of diabetes, animals were kept for seven days without any treatment for the development of diabetes.

Arterio-venous blood from the tail vein of the rats was taken for the assessment of blood glucose levels. Non-diabetic animals were excluded from the experiment. 
<smiles>CCc1c(C(O)CN2CCN(P)CC2)oc2ccccc12</smiles>

$\mathrm{R}^{2}=-4$ - fluorophenyl

Figure 1. Chemical structure of the substance 4/1E

The treatment of animals with suspension of Pycnogenol $(20 \mathrm{mg} / \mathrm{kg}$ p.o. $)$ and 4/1E (10 mg/kg i.p.) lasted for 6 weeks according to the randomisation in groups. The substance 4/1E (Fig.1) was synthesised at the Faculty of Pharmacy, University of Veterinary and Pharmaceutical Sciences in Brno, Czech Republic. Chemically, it refers to heteroaryloxyaminoethanolic derivatives. Pycnogenol ${ }^{\circledR}$ is a standardised flavonoic extract that was kindly donated by Dr. Minczinger, Generica, Piestany.

To one group of diabetic (DL), healthy control (L) and hypertensive (HL) animals the substance 4/1E was administered. To the one group of diabetic (DP) and hypertensive (HP) animals Pycnogenol ${ }^{\circledR}$ was administered. One group of healthy control (C), hypertensive (H) and diabetic (D) rats were administered physiological solution. These groups served as controls.

\section{RESULTS}

The activity of NAGA (Fig. 2) showed no significant changes in the group of untreated hypertensive animals compared to healthy control animals. A decreasing trend was shown after administration of Pycnogenol ${ }^{\circledR}$, although it was not significant. The NAGA activity was significantly increased in diabetic untreated animals compared to the control group. Neither treatment with $4 / 1 \mathrm{E}$ nor treatment with Pycnogenol ${ }^{\circledR}$ showed significant improvement.

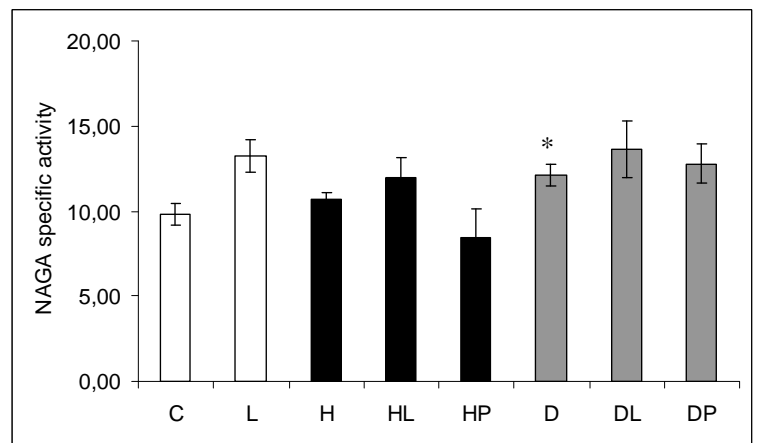

Figure 2. Specific activity NAGA. * - p<0.05 vs. C 

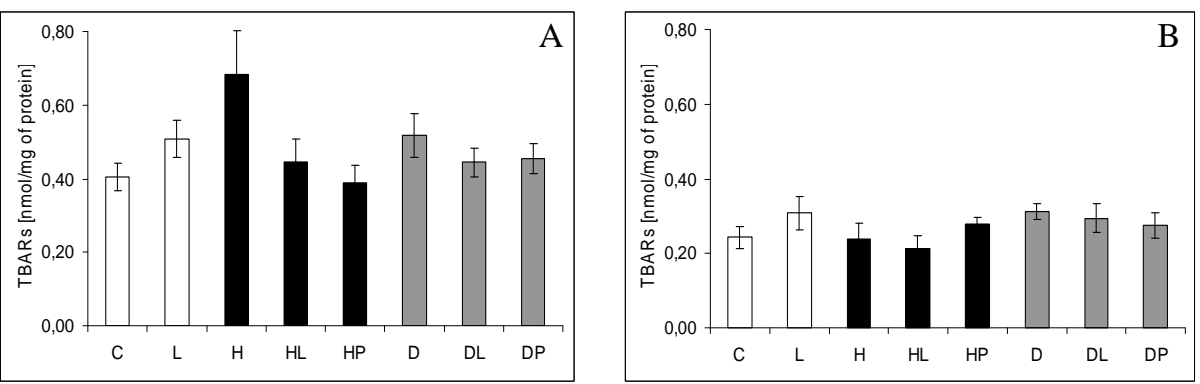

Figure 3. The levels of TBARs in kidney (A) and liver (B)

TBARs levels in the kidney (Fig. 3A) were slightly increased in both groups: hypertensive and diabetic. Both treatments with 4/1E and Pycnogenol ${ }^{\circledR}$ decreased the levels of TBARs in all hypertensive and diabetic treated groups of animals, although it was not statistically significant. The levels of TBARs in liver (Fig. 3B) were not changed significantly in any of the untreated or treated experimental groups of animals.

The expression of eNOS (Fig. 4) in hypertensive animals was not changed compared to healthy control animals. In diabetic animals the expression of eNOS was increased compared to healthy ones (D: $52.22 \% \pm 6.49 \%$ vs. C: $100.00 \% \pm 14.14 \%$ ). The treatment with $4 / 1 \mathrm{E}$ did not show any effects on expression of eNOS in either of the treated groups. Pycnogenol ${ }^{\circledR}$ administration led to decrement of eNOS expression in hypertensive animals but significant increase in the group of treated diabetic animals (DP: $170.47 \% \pm 17.17 \%, \mathrm{p}<0.01)$.

The expression of Hsp90 (Fig. 5) in both groups, hypertensive and diabetic animals, was increased compared to healthy control animals (H: $137.40 \% \pm 17.92 \%$, D: $151.06 \%$ $\pm 17.40 \%$ vs. C: $100.00 \% \pm 16.33 \%$ ). The administration of $4 / 1 \mathrm{E}$ decreased Hsp90 expression, in both the hypertensive and diabetic groups (HL: $74.71 \% \pm 16.06 \%$, DL: $85.78 \% \pm 8.63 \%, \mathrm{p}<0.05$ vs. D). Administration of Pycnogenol ${ }^{\circledR}$ was effective in lowering the levels of Hsp90 compared to untreated diabetic animals also (HP: $93.60 \%$ $\pm 10.47 \%$, DP: $115.78 \% \pm 18.43 \%)$.

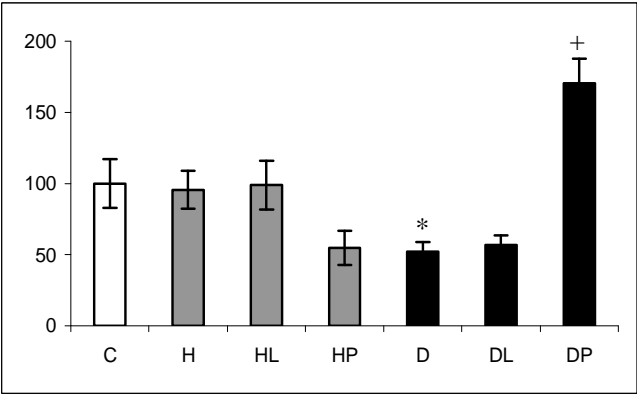

Figure 4. The expression of eNOS. Values are expressed as the mean \pm standard error of the mean. $*$ p $<0.05$ vs. $\mathrm{C},{ }^{+} \mathrm{p}<0.01$ vs. $\mathrm{D}$

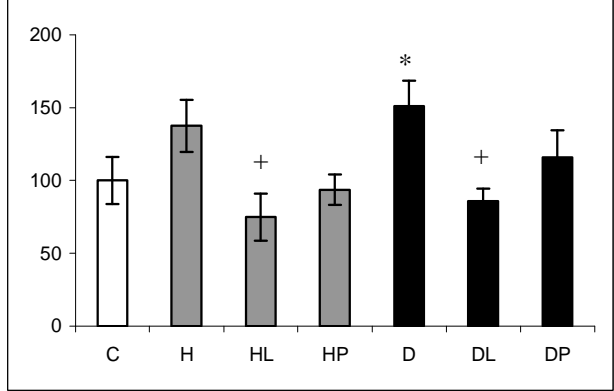

Figure 5. The expression of Hsp90. Values are expressed as the mean \pm standard error of the mean. ${ }^{*} \mathrm{p}<0.05$ vs. $\mathrm{C},{ }^{+} \mathrm{p}<0.05$ vs. $\mathrm{D}$ 


\section{DISCUSSION}

Hypertension and diabetes are two main factors for development of cardiovascular complications. Both of them speed up the progression of microvascular and macrovascular complications [12]. The oxidative stress produced by hyperglycaemia in diabetic condition causes alterations of the endothelium and thus endothelial dysfunction. Hypertension, which in many cases presents together with diabetes, causes a similar state. This study focused on changes in the levels of oxidative stress assessed as the levels of thiobarbituric acid reactive substances and the activity of N-acetyl- $\beta$-Dglucosaminidase and expression of two important proteins: endothelial NO-synthase and heat shock protein 90 after a 6-week administration of newly synthesised betablocker 4/1E and the natural antioxidant Pycnogenol ${ }^{\circledR}$.

Various studies presented contradictory results in observation of eNOS expression in diabetic state: either increased [13] or decreased [14]. The decrement in the formation of the Hsp90-eNOS complex in diabetic rats was also proved [15]. In our study, the expression of eNOS was decreased just in diabetic animals. The significant increase of eNOS was observed only after administration of Pycnogenol ${ }^{\circledR}$. The agent 4/1E was not able to improve the eNOS expression. The expression of Hsp90 was increased in both hypertensive and diabetic animals. Better effects in lowering of Hsp90 expression were shown after administration of the agent 4/1E than after administration of Pycnogenol ${ }^{\circledR}$. The increase of eNOS activity and NO bioavailability showed favourable effects since NO is the crucial factor for normal blood pressure maintaining [16]. In hypertensive animals as well as in hypertensive patients, impairment of NO-dependent vasodilation was found. It is unclear whether this impairment is the result of decrease in NO synthesis or its increased consumption. In the model of spontaneously hypertensive rats the production of NO was comparable to normotensive ones, however the levels of superoxide radical were increased. This led to the oxidation of NO resulting in the decrease of the vasodilatory vessels' response [16].

The positive effects of Pycnogenol ${ }^{\circledR}$ on the expression of eNOS could be associated with its ability to lower blood glucose levels [10] and stronger antioxidant activity compared to the agent 4/1E. Treatment with Pycnogenol ${ }^{\circledR}$ showed better results in hypertensive animals than treatment with agent $4 / 1 \mathrm{E}$. The effects of newly synthesised drug 4/1E and Pycnogenol ${ }^{\circledR}$ on the levels of oxidative stress were in our study comparable in diabetic animals.

Although new synthesised agent 4/1E showed desired effects on lowering levels of oxidative stress in kidney and expression of Hsp90 in heart in hypertensive and diabetic animals, these are not distinctive enough to suggest agent 4/1E for follow-up trials.

Acknowledgement: This project was supported by the grants UK/32/2010 and FaF UK/25/2009. The authors thank Mrs Veronika Hassova for her excellent technical assistance. 


\section{REFERENCES}

1. HAMDEN, K. - BOUJBIHA, M.A. - MASMOUDI, H. - AYADI, F.M. JAMOUSSI, K. - ELFEKI, A. Combined vitamins (C and E) and insulin improve oxidative stress and pancreatic and hepatic injury in alloxan diabetic rats. Biomed Pharmacother. 63, 2009, p. 95-109.

2. INOGUCHI, T. - SONTA, T. - TSUBOUCHI, H. - ETOH, T. - KAKIMOTO, M. - SONODA, N. a kol. Protein kinase C-dependent increase in reactive oxygen species (ROS) production in vascular tissues of diabetes role of vascular NAD $(\mathrm{P}) \mathrm{H}$ oxidase. J Am Nephrol. 14, 2003, p. S227-S232.

3. SHIBA, T. - INOGUCHI, T. - SPORTSMAN, J.R. - HEATH, W.F. - BURSELL, S. - KING, G.L. Correlation of diacylglycerol level and proteinkinase $\mathrm{C}$ activity in rat retina to retinal circulation. Am J Physiol. 265, 1993, p. E783-793.

4. RICHTER, K. - BUCHNER, J. Hsp90: chaperoning signal transduction. J Cell Physiol. 188, 2001, p. 281-290.

5. KOMATSUDA, A. - WAKUIL, H. - IMAI, H. - ITOH, H. - YASUDA, T. MIURA, A.B. Expression of $90-\mathrm{kDa}$ heat shock protein within regenerative tubular cells in a patient with acute oliguric renal failure due to malignant hypertension. Ren Fail. 21, 1999, p. 113-117.

6. PIECH, A. - DESSY, C. - HAVAUX, X. - FERON, O. - BALLIGAND, J.L. Differential regulation of nitric oxide synthases and their allosteric regulators in heart and vessels of hypertensive rats. Cardiovasc Res. 57, 2003, p. 456-67.

7. JAY, D. - HITOMI, H. - GRIENDLING, K.K. Oxidative stress and diabetic cardiovascular complications. Free Rad. Biol. Med. 40, 2006, p. 183-192.

8. JANKYOVÁ, S. - PREKOPOVÁ, K. - CSÖLLEI, J. - RAČANSKÁ, E. Analýza základných farmakologických vlastností novosyntetizovaných heteroarylaminoetanolov. Pokroky vo farmakológii v Slovenskej republike, Bratislava, 2009, p. 14-19.

9. LIU, X. - ZHOU, H.J. - ROHDEWALD, P. French Maritime Pine Bark Extract Pycnogenol Dose-Dependently Lowers Glucose in Type 2 diabetic Patients. Diabetes Care, 27, 2004, p. 893-896.

10. JANKYOVA, S. - KUCERA, P. - GOLDENBERG, Z. - YAGHI, D. NAVAROVA, J. - KYSELOVA, Z. - STOLC, S. - KLIMAS, J. - RACANSKA, E. - MATYAS, S. Pycnogenol ${ }^{\circledR}$ Efficiency on Glycaemia, Motor Nerve Conduction Velocity and Markers of Oxidative Stress in Mild Type Diabetes in Rats. In press, Phytother. Res. 23, 2009, p. 1169-1174.

11. MARITIM, A.C. - DENE, B. A. - SANDERS, R. A. - WATKINS III, J. B. Effects of Pycnogenol Treatment on Oxidative Stress in Streptozotocin-Induced Diabetic Rats. J Biochem Molecular Toxicology, 17, 2003, p. 193-199.

12. WOOD, D. - DE BACKER, G. - FAERGEMAN, O. - GRAHAM, I. - MANCIA, G. - PYÖRÄLÄ, K. Prevention of coronary heart disease in clinical practice. Recommendations of the Second Joint Task Force of European and other Societies on Coronary Prevention. Eur Heart J, 19, 1998, p. 1434-1503.

13. COSENTINO, F. - HISHIKAWA, K. - KATUSIC, Z.S. - LÜSCHER, T.F. High glucose increases nitric oxide synthase expression and superoxide anion generation in human aortic endothelial cells. Circulation. 96, 1997, p. 25-28.

14. SRINIVASAN, S. - HATLEY, M.E. - BOLICK, D.T. - PALMER, L.A. EDELSTEIN, D. - BROWNLEE, M. - HEDRICK, C.C. Hyperglycaemia-induced superoxide production decreases eNOS expression via AP-1 activation in aortic endothelial cells. Diabetologia. 47, 2004, p. 1727-1734. 
15. STALKER, T.J. - SKVARKA, C.B. - SCALIA, R. A novel role for calpains in the endothelial dysfunction of hyperglycemia. FASEB J. 17, 2003, p. 1511-1523.

16. HEITZER, T. - BROCKHOFF, C. - MAYER, B. - WARNHOLTZ, A. MOLLNAU, H. - HENNE, S. - MEINERTZ, T. - MÜNZEL, T. Tetrahydrobiopterin improves endothelium-dependent vasodilatation in chronic smokers: evidence for a dysfunctional nitric oxide synthase. Circ Res. 86, 2000, p. E36-41.

Registered: April 18, 2011

Accepted: May 20, 2011
PharmDr. Stanislava Jankyova, PhD.

Faculty of Pharmacy

Comenius University

Odbojárov 10

83232 Bratislava

Slovak Republic

jankyova@fpharm.uniba.sk

\title{
HODNOTENIE ÚČINNOSTI NOVOSYNTETIZOVANÉHO DERIVÁTU A PRÍRODNÉHO ANTIOXIDANTU V LIEČBE DIABETICKÝCH A HYPERTENZNÝCH POTKANOV
}

\author{
${ }^{1}$ Jankyová, S. - ${ }^{1}$ Adameová, A. $-{ }^{1}$ Slažneva, J. $-{ }^{2}$ Navarová, J. - ${ }^{3}$ Drobná, V. $-{ }^{4}$ Csollei, J . - \\ ${ }^{1}$ Račanská, $E$. \\ ${ }^{1}$ Katedra Famakológie a toxikológie, Farmacetická fakulta, \\ Univerzita Komenského, Bratislava \\ ${ }^{2}$ Ústav Experimentálnej farmakológie a toxikológie, \\ Slovenská Akadémia Vied, Bratislava \\ ${ }^{3}$ Ústav Farmakológie a Klinickej farmakológie, Lekárska fakulta \\ Univerzita Komenského, Bratislava \\ ${ }^{4}$ Farmaceutická fakulta, Veterinárna a Farmaceutická Univerzita, \\ Brno, Česká republika
}

\begin{abstract}
Hypertenzia, ktorá sa rozvíja v dôsledku kardiovaskulárneho poškodenia v diabete patrí medzi vážne diabetické komplikácie. Ciel'om tejto štúdie bolo zhodnotit' zmeny hladín oxidačného stresu a expresie endotelovej NO syntázy (eNOS) a heat shock proteínu 90 (Hsp90) po liečbe novosyntetizovaným potenciálnym beta-blokátorom 4/1E a prírodným antioxidantom Pycnogenolom ${ }^{\circledR}$ u diabetických a hypertenzných potkanov. Šest'týždňová liečba bola indikovaná v skupine diabetických Wistar potkanov (DL, streptozotocín (STZ) 3x25 mg/kg i.p.) a hypertenzných potkanov (HL, STZ) látkou 4/1E v dávke $10 \mathrm{mg} / \mathrm{kg}$ i.p. alebo Pycnogenolom ${ }^{\circledR}$ (DP, HP) v dávke $20 \mathrm{mg} / \mathrm{kg}$, p.o. Zvieratá v kontrolných skupinách $(\mathrm{C}, \mathrm{H}, \mathrm{D})$ dostávali vehikulum. Hladiny oxidačného stresu boli stanovené v obličke a pečeni ako aktivita N-acetyl- $\beta$ D-glukózaminidázy (NAGA) a hladina reaktívnych foriem kyseliny tiobarbiturovej (TBARs). Expresia eNOS a Hsp90 bola stanovená zo srdca použitím metódy SDS-PAGE a Western Blotting. Účinok novosyntetizovanej látky 4/1E a Pycnogenolu ${ }^{\circledR}$ na hladiny oxidačného stresu bol porovnatel'ný len pri aplikácii u diabetických, nie hypertenzných zvierat. Expresia eNOS a Hsp90 bola znížená u diabetických, nie však hypertenzných zvierat.
\end{abstract}


Liečba látkou 4/1E neovplyvnila expresiu eNOS, narozdiel od Pycnogenolu ${ }^{\circledR}$, kedy došlo k signifikantnému zvýšeniu expresie eNOS. Expresia Hsp90 bola zvýšená u hypertezných aj diabetických zvierat. Liečba látkou 4/1E bola účinnejšia v znižovaní expresie Hsp90 u oboch skupín zvierat než podávanie Pycnogenolu ${ }^{\circledR}$.

Práca bola podporená grantmi: UK/32/2010 and FaF UK/25/2009.

Acta Facult. Pharm. Univ. Comenianae 58, 2011, p. 28 - 36. 